\title{
Exploratory Learning as a Driver of Performance: Integrating the Effects of Knowledge Stock and Resource Flexibility in the Context of Commercial Banks in Kenya
}

\author{
Paul Thumbi Njoroge \\ School of Business, Kenyatta University, Nairobi, Kenya
}

\section{Email address:}

paultnjoroge@gmail.com

\section{To cite this article:}

Paul Thumbi Njoroge. Exploratory Learning as a Driver of Performance: Integrating the Effects of Knowledge Stock and Resource Flexibility in the Context of Commercial Banks in Kenya. Journal of Business and Economic Development. Vol. 6, No. 2, 2021 , pp. 104-114. doi: 10.11648/j.jbed.20210602.16

Received: April 12, 2021; Accepted: May 3, 2021; Published: June 4, 2021

\begin{abstract}
Exploratory learning is critical in building organizational capability for performance that guarantees future viability and sustainability of the business. Research delving into the nexus between exploratory learning and performance is limited in the context of developing economies. The purpose of this paper was to examine the relationship between exploratory learning and performance and establish the conceptual nature of this relationship by determining the effect of knowledge stock and resource flexibility on this linkage and determine the effect of exploratory learning variables on performance dimensions in the context of commercial banks in Kenya. The study adopted descriptive research design in which a sample of 140 participants from commercial banks in Kenya was selected using stratified random sampling method. Data was collected using a questionnaire administered to management level staff. Multiple regression analysis and correlation analysis were used for hypotheses testing. The results established that knowledge stock which was indicated by tacit knowledge, routines and procedures, and competencies and skills has significant influence on exploratory learning. It provides the capabilities for searching for knowledge of new markets, new technology and new product development. Exploratory learning has a statistically significant positive correlation with performance and has high influence on process efficiency, product quality and customer satisfaction. Resource flexibility was found to have moderating effect on the relationship between exploratory learning and performance. It was found that organizations gain value through bundling and leveraging resource portfolios in the management of scarce resources to the extent that priority is given to high yielding opportunities, cost effective projects and efforts that respond to market, product and customer changes. The study suggests that to enhance firms' performance, firms should enhance their knowledge capacity, invest in exploratory learning activities and leverage resources for search and operationalization of new markets, new product development and implementation of new technology.
\end{abstract}

Keywords: Exploratory Learning, Knowledge Stock, Organizational Learning, Performance, Resource Flexibility

\section{Introduction}

Irrespective of the industry and sector of operation, the chronic business environment witnessed today poses challenge of sustainability and firms have to be flexible, agile and innovative. To achieve this level of effectiveness requires a learning capability that enables the firm to adapt to changing environment [1] characterized by disruptions ranging from technological, socio-cultural, political and natural invasions such as COVID-19. Besides exploiting the current capabilities, organizations are required to explore new opportunities that happen as a result of disruptions. This situation renders exploratory learning a critical capability for any organization's current stability and future viability [2]. Therefore, the biggest question is how organizations can align and implement exploratory learning activities for organizational performance.

Exploratory learning entails the acquisition and utilization of new knowledge and skills to change current technological processes through innovative efforts [3]. Exploratory learning is conceptualized to involve the constructs of searching, innovation, creative experimentation through new knowledge 
for organizational survival and flexibility [4]. Empirically, the concept has been studied as acquisition of new knowledge and skills for technological advancement, new product and process development, managerial and organizational arrangement for innovative solutions [5-7].

Extant literature is inconclusive on the influence of exploratory learning on firm performance with some studies showing contradicting findings [2, 7-9]. This may partly be explained by the differing measures adopted to operationalize the constructs of exploratory learning and conceptual models used to study the relationship $[1,10]$. Further, the contradictory results may be attributed to the multiplicity of approaches, theories and models adopted to measure performance. It is argued that each organization is unique and operates within a unique micro and macro environment which makes measurement of performance both situational and contextual [11]. This view affirms that exploratory learning activities of a firm should be studied and understood within the micro and macro contexts they operate in.

The antecedents and moderators of the relationship between exploratory learning and organizational performance has not fully been exhausted [12]. Therefore, the purpose of this study was to examine the linkage between exploratory learning and performance by establishing the conceptual nature of this relationship in terms of antecedent effect of knowledge stock and moderating effect of resource flexibility on the linkage. Further, the study sought to determine how firms can leverage the complementarities of these nexus for enhanced performance in commercial banks in Kenya.

The paper is organized such that it first presents the theoretical underpinning of the study. This is followed by a critical review of relevant empirical literature and a conceptual framework of the study. Next, the research method and findings are presented consecutively. Finally, conclusions, practical implications and suggestions for further study are presented.

\section{Literature Review}

\subsection{Organizational Learning Theory}

Research on organizational learning has remained prominent for the last three decades owing to its centrality to performance. The primary focus of much of this literature and studies has been on three critical components of learning, that is, acquisition, distribution and utilization of knowledge [13]. The seminal work of March [4] on organizational learning provide a theoretical underpinning upon which research on exploratory learning and performance is founded. The theory advances the significance of exploratory learning on a firm's performance. The concept of exploratory learning involves the idea of searching, innovation, creative experimentation through new knowledge for current and future viability of the firm.

Exploratory learning, which entail pursuit of new knowledge beyond the existing scope of knowledge, aims at the development of new knowledge that increases organizational innovative capability and flexibility [14, 15]. It is argued that organizations need to engage in exploratory learning activities for future viability as it provides organizations the flexibility necessary for growth $[8,12,16]$. Other scholars emphasis on the significance of exploratory learning on firm's adaptability to environmental exigencies [9, 17-19] and competitive advantage [20]. However, there others that argue that over-emphasis on exploration risks putting the organization in an endless search which may drain resources without direct benefits [3] and that $t$ exploratory learning exhausts financial resources which may lead to liquidity problems as the benefits may take time to be realized and firms risk the short-term profitability if they singularly focus on exploratory learning [17].

The concept of exploratory learning has been operationalized and understood using the prism built by March [4], albeit with slight adjustments to suit research objectives [7, 20-22]. This demonstrates that the difference in measurement of exploratory learning in extant literature is more of expediency rather than of fundamental divergence. The indicators of exploratory learning are referenced by constructs of searching for new knowledge and skills, variation in operations, risk taking orientation, experimenting different options, pursuit of organizational flexibility, discovery and innovation of new and creative technologies [6]. Another taxonomy of exploratory learning that has been validated empirically, entail acquisition of new technological skills, new product and process development skills, and acquisition of new innovation skills $[5,7]$. On the other hand, some studies have measured exploratory learning in terms of new knowledge acquisition and processing that involve elements of experimentation and risk taking, new knowledge of markets, technologies and product development beyond current experiences and scope [17, 23-26].

\subsection{Knowledge-Based View}

The knowledge-based view (KBV) propounds the significance of knowledge as a critical resource for organizational competitiveness and innovative capabilities because of the rarity and inimitable nature of knowledge [27, 28]. With organizations evolving into learning organizations, knowledge has become a strategic resource [29]. Empirical evidence points to the positive influence of knowledge stock on learning and on organizational outcomes [6, 30, 31]. It is acknowledged that knowledge is significant in learning processes and exploratory learning ensue from different knowledge processing paths [3, 13, 14, 32].

A firm's knowledge capacity transcends an organization's system, operations, technology, human resources and all facets of the organization [28]. Therefore, knowledge is at the centre of organizational learning. It is held that new knowledge acquisition is facilitated by the existing knowledge, that is, knowledge stock or capital, which refers to prior knowledge is the precursor of continuous learning [31-35]. These arguments support the view that knowledge stock is an antecedent of exploratory learning as it guides the way new information and knowledge is manipulated for positive organizational 
outcomes. It is clear that knowledge stock provides the elements and capabilities that cements the impact of learning on firm performance $[6,36,37]$. Therefore, KBV theory helps explain the relationship between knowledge stock, exploratory learning and performance [4, 6, 37-39].

\subsection{Dynamic Resource Management View}

Resource flexibility is critical to implementation of organizational learning processes, in particular, exploratory learning activities are only effective to the extent that the firm is capable to dynamically manage and reconfigure the scarce resources rather than rely on availability or accessibility of resources [40-45]. The dynamic resource management view holds that firms gain value through bundling and leveraging resource portfolios [45]. Resource portfolio is achieved by a firm investing in new resources, enhancing the capacity of internal resources by developing them, and creating new bundles of resources [23, 43]. The theory illuminates the understanding of the complementary view which proposes that firms should take advantage of the unique features of exploratory learning, which focuses on new knowledge, and exploitation of existing knowledge by bundling resources [21, 23].

Extant literature postulate that resource endowment should not constrain organizations pursuit of exploratory learning because firms can escape this resource trap by creating heterogeneous resources [41, 44]. There is need for coordination flexibility in the management of scarce resources in order to create synergistic impact necessary for exploratory learning [45]. Some scholars have called for more research to focus on how firms can dynamically structure, bundle, and leverage scarce organizational resources to benefit from exploratory learning [42]. The dynamic resource management theory explains the effect of resource flexibility on the relationship between exploratory learning and performance $[23,45]$.

\subsection{Organizational Performance}

The measurement of organizational performance is controversial issue that has lingered for decades with researchers exercising abandon in adoption of measures and indicators. This has been made possible by the multiplicity of approaches, theories and models of organizational performance. Each organization is unique and operates within a unique micro and macro environmental making measurement of performance both situational and contextualized. Making a framework or model of performance measurement hence becomes difficult as these measures become contingent to a firm [40]. Nevertheless, there is need to use a model that encapsulates measures applicable in diverse contexts for ease generalization of research findings. The balanced scorecard (BSC) provides a framework that captures a broad view of performance $[46,47]$.

The balanced scorecard is a management and performance measurement model for organizational effectiveness developed and advanced by Kaplan and Norton [46]. The
BSC was developed to help organizations leverage on its different organs in pursuit of effectiveness and competitive advantage. The BSC Model provides a reliable set of performance indicators (KPIs) useful in evaluating and measuring performance of an organization against a set of strategic objectives. The model comprises four perspectives that determine the scope of assessment: financial, customer, learning and growth and internal processes perspectives [47]. The significance of this model is that it provides a balanced view of indicators from both external and internal. The external indicators represented by customers or stakeholders and the internal indicators comprise the organizational critical processes, learning and innovative capabilities and development. This ensures a complementarity between financial and non-financial measures of performance [1].

\subsection{Exploratory Learning and Performance}

A review of empirical literature on exploratory learning and performance reveals conflicting results. There has been a multiplicity of approaches, theories and frameworks adopted by various scholars to study the concepts. Early studies drew a link between exploratory learning and performance with declaration that exploratory learning activities are critical to organization's capacity to adapt to changing environment [22]. It is also viewed that exploratory learning provides organizations the flexibility necessary for growth [16], increases organizational innovative capability and flexibility $[7,9,20]$ and gives businesses competitive advantage [20, 24]. However, some studies have found negative association between exploratory learning and perfor4mance, found contingent effect, or no relationship.

Recent studies have delved into the debate with conflicting results. For instance, a study established that knowledge stock influenced exploratory learning which ultimately determined superior performance of technologically intensive firms in China [23] while another concluded that appropriating exploratory learning activities at employees' level increases the firm's chances of growth and survival [18]. Some studies reveal that the exploratory learning influences the innovative performance in SMEs [19] and that SMEs with the appropriate organisational contexts increase their potential for growth and survival through exploratory activities [18]. Exploratory learning shapes the extent of a firm's innovative capability, which resides in its people [21] and innovative behaviour is influenced by exploratory learning activities [12].

Studies have been conducted to examined $\backslash$ how firms should dynamically reconfigure resource portfolios to leverage organizational ambidexterity for new product development. The results indicated that exploratory dimension has an inverse U-shaped effect on new product development and that resource flexibility has positive moderating effects on the relationships between the exploratory and exploitative dimensions of ambidexterity and new product development performance. Further, firms gain value through bundling and leveraging resource portfolios in the management of scarce resources in order to create 
synergistic impact necessary for exploratory learning and consequently enhanced organizational performance [45]. Therefore, there is need for firms to dynamically structure, bundle, and leverage scarce organizational resources to benefit from exploratory learning $[42,44]$.

Reviewing the contextual and methodological approaches used in past studies on the relationship between exploratory learning and performance, reveal a glut of empirical literature in the developed economies and a scarcity of research in developing economies $[6,7,19,30]$. Empirical studies have been carried out in developed contexts in Europe and Asia to examine the relationships among knowledge stock, exploratory learning, and firm performance, exploration on how firms should dynamically reconfigure resource portfolios to leverage organizational learning for new product development, the extent to which exploration and exploitation at employee level influenced innovative work behaviour and the influence of organizational learning capability and organizational creativity on organizational innovation $[6,12,26,30,32$, $44,45]$.

The measures used for exploratory learning in empirical literature have largely been informed by March [4] seminal work, albeit with slight adjustments to suit specific research objectives. The indicators of exploratory learning are referenced by constructs of search, variation, risk taking, experimentation, play, flexibility, discovery and innovation. Empirical literature reveals a long continuum of indicators of exploratory learning that include measures of competence exploration which entail acquisition of new technological skills new product and process development skills, new managerial and organizational skills for innovation, acquisition of new innovation skills, acquisition of new knowledge involving experimentation and risk taking, new knowledge of markets, technologies and product development beyond current experiences and scope [4-7, 20, 22, 23].

Measureent of organizational performance in empirical studies reveal a multi-dimensional approach. Scholars have adopted different models informed by the objectives and scope of their studies. For instance, in organizational learning literature $[5,7]$ financial indicators such as ratio of new product sales to total sales, to measure new product performance have been used. Other measures used include returns on assets (ROA) [6], customer loyalty, sales growth, profitability and return on investment [19]. These measures of performance are largely financial and relegate the significance of non-financial measures which are critical in order to provide a broader view of performance. Organizational learning literature points to unquantifiable outcomes of implementing learning activities [1]. Scales of non-financial measures proposed in human resource management literature [49], the Sink and Tuttle Model [48] and Kaplan and Norton's balanced scorecard [46] are more precise for measuring performance outcomes predicted by organizational learning activities [1].

\subsection{Conceptual Framework}

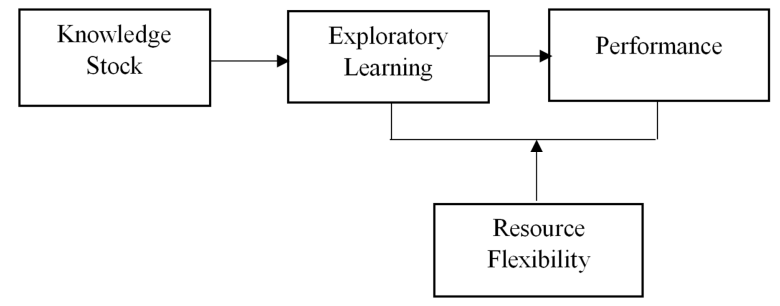

Source: Njoroge (2021)

Figure 1. Conceptual Framework.

\subsection{Research Hypotheses}

From the conceptual framework, it was hypothesized that:

$\mathrm{HO}_{1}$ : There is no relationship between knowledge stock and exploratory learning in commercial banks in Kenya

$\mathrm{HO}_{2}$ : There is no relationship between exploratory learning and performance in commercial banks in Kenya

$\mathrm{HO}_{3}$ : Knowledge stock has no effect on exploratory learning in commercial banks in Kenya

$\mathrm{HO}_{4}$ : Exploratory learning has no effect on performance in commercial banks in Kenya

$\mathrm{HO}_{5}$ : Resource flexibility has no moderating effect on the relationship between exploratory learning and performance in commercial banks in Kenya

\section{Methodology}

\subsection{Research Design and Sampling}

Positivist research philosophy and descriptive research design were adopted for the study. Positivist research philosophy is appropriate for explaining relationships between variables with cause and effect attribute [50]. Further, positivism is ideal for research that progresses from problem statement, setting of objectives and hypothesis formulation and testing and generalization of findings through statistical probability $[50,51]$. The descriptive design was found more reliable and suitable in determining the relationships between variables, establishing models of these relationships and testing hypotheses [52]. Crosssectional survey method was used as data was collected and the relationship between variables measured at a specified time.

The context of the study was commercial banks in Kenya. The target population comprised seven (7) first tier and commercial banks in Kenya. These banks are Kenya Commercial Bank, Equity Bank, Diamond Trust Bank, NCBA Bank, Absa Bank Kenya, Cooperative Bank of Kenya, and Standard Chartered Bank of Kenya [53]. A representative sample was selected using stratified random sampling method from five sections of each bank, that is, human resources, operations, finance, information communication technology and business development. Two management level staff were selected for the survey in each section. Therefore, the sample size comprised 140 participants. 


\subsection{Data Collection and Procedure}

Data was collected using questionnaire as it is the most appropriate instrument for data collection in descriptive research [52]. The questionnaire comprised both open-ended and closed questions which is critical in providing more insights and flexibility [54]. The questionnaire was structured into five sections: the first section contained bio data information; section two, knowledge stock questions; section three, exploratory learning questions; section four, resource flexibility questions; and section five, performance questions. The questionnaires were sent to the respondents via email and they were required to send back the filled in forms through the same means.

\subsection{Validity and Reliability}

The research instrument was tested for validity and reliability to ensure that it measures what it is purported to measure and that it would yield similar results in repeated survey. To ascertain validity, the researcher adapted measures that have been validated in previous studies. To test the reliability of the quantitative measures, Cronbach's Alpha Coefficient statistical method was used since it is considered suitable for measuring internal consistency when multiple Likert questions have been used [52]. Internal consistency of questionnaire items was considered adequate if they had a Cronbach's alpha coefficient value of 0.7 or higher [55].

\subsection{Measurement of Variables}

The four variables which form the conceptual framework of the study were operationalized based on empirically validated measures. The indicators of knowledge stock, which include tacit knowledge, routines, existing competences and skills, and internal experts, were adapted from past studies [6]. The indicators of exploratory learning were adapted from the scale of measures used in past studies [5]. Exploratory learning activities were measured in terms of acquisition of new knowledge involving experimentation and risk taking, new knowledge of markets, technologies and product development beyond current experiences and scope. For performance, non-financial measures were adapted as developed by Kaplan and Norton [47]. The constructs of performance included process efficiency, product quality, customer satisfaction and employees' productivity. The moderator, resource flexibility, was operationalized based on past studies [21, 23, 45] which measures resource flexibility in terms of structuring, bundling and leveraging scarce resources.

\subsection{Data Analysis}

Data was analyzed and interpreted using descriptive and inferential statistics. The descriptive statistics used were mean and standard deviation and inferential statistics done included multiple regression and correlation analyses to measure causal relationship between and among study constructs and test hypotheses. In particular, regression analysis was used to test hypotheses to establish if there was a statistically significant relationship between knowledge stock and exploratory learning constructs, and exploratory learning constructs and performance. In addition, these analyse aided in examining how changes in the predictor variables influence and predict the dependent variable. Pearson correlation was used to determine the association between the explanatory and dependent variables, knowledge stock, exploratory learning and performance. The strength and direction of linear relationships between pairs of study variables were measured.

\section{Results and Discussions}

\subsection{Reliability of Research Instrument}

The results of reliability test presented in table 1 reveal that the questionnaire had internal consistency with all items having a coefficient value greater than 0.7 as recommended [55].

Table 1. Reliability Test Results.

\begin{tabular}{llll}
\hline Variables & Measures & No. of Items & Cronbach's Alpha \\
& Tacit knowledge & 3 & 0.726 \\
Knowledge Stock & Routines and procedures & 3 & 0.891 \\
& Existing competencies and skills & 3 & 0.788 \\
& Knowledge of new markets & 3 & 0.767 \\
Exploratory Learning & Knowledge of new technology & 3 & 0.801 \\
& Knowledge of new products & 3 & 3 \\
Resources Flexibility & Structuring & 3 & 0.833 \\
& Bundling & 3 & 0.768 \\
& Leveraging & 3 & 0.826 \\
Performance & Process efficiency & 3 & 0.877 \\
& Product quality & 3 & 0.855 \\
\end{tabular}

Source: Njoroge (2021).

\subsection{Response Rate}

One hundred and forty (140) questionnaires were administered to respondents out of which one hundred and nineteen (119) were completed representing 85 per cent response rate. The response rate was high enough to proceed with data analysis [55]. 


\subsection{Knowledge Stock and Exploratory Learning}

A nine-item scale was used to establish the extent to which knowledge stock was applied for exploratory learning. Using a five-point Likert scale from 1 "very low" to 5 "very high," respondents were required to indicate the extent to which measures of knowledge stock were used to impact the four measures of exploratory learning. The results are summarized in table 2 .

Table 2. Knowledge Stock and Exploratory Learning.

\begin{tabular}{|c|c|c|c|c|c|c|}
\hline Statement/ Knowledge Stock & Exploratory Learning Indicators & $\mathbf{N}$ & Min & Max & Min & Std Dev \\
\hline \multirow{3}{*}{$\begin{array}{l}\text { Extent to which tacit knowledge is } \\
\text { utilized for exploratory learning }\end{array}$} & Knowledge of new markets & 119 & 1 & 5 & 3.899 & 0.977 \\
\hline & Knowledge of new technology & 119 & 1 & 5 & 3.775 & 0.782 \\
\hline & Knowledge of new products & 119 & 1 & 5 & 4.152 & 0.888 \\
\hline \multirow{4}{*}{$\begin{array}{l}\text { Extent to which routines and } \\
\text { procedures are used for exploratory } \\
\text { learning } \\
\text { Extent to which existing competencies } \\
\text { and skills are used for exploratory } \\
\text { learning }\end{array}$} & Knowledge of new technology & 119 & 1 & 5 & 3.633 & 0.967 \\
\hline & Knowledge of new products & 119 & 1 & 5 & 3.548 & 0.996 \\
\hline & Knowledge of new markets & 119 & 1 & 5 & 4.284 & 0.752 \\
\hline & Knowledge of new products & 119 & 1 & 5 & 4.251 & 0.714 \\
\hline
\end{tabular}

Source: Njoroge (2021).

The results presented in table 2 show that to a relatively high degree commercial banks utilize their knowledge stock for exploratory learning dimensions of searching for knowledge of new markets, new technology and new products development. Tacit knowledge is mainly applied in search for new markets (Mean 3.899) and knowledge of new products development (Mean 4.152). Routines and procedures are largely important for search for knowledge of new technology (Mean 3.633). On the other hand, existing competencies and skills are critical for search for new knowledge of markets (Mean 4.284), knowledge of new technology (Mean 4.166) and knowledge of new products (Mean 4.251). It is evident that tacit knowledge and existing competencies and skills are more critical to exploratory learning than routines and procedures. These findings points to the significance of knowledge stock in exploratory learnings as evidenced in other studies $[6,12,22]$.

\subsection{Exploratory Learning and Performance}

The study sought to determine the degree to which the respondents felt that exploratory learning dimensions influenced performance indicators of process efficiency, product quality and customer satisfaction. Using a five-point Likert scale from 1 "very low" to 5 "very high," respondents were required to indicate the degree of influence. The results are summarized in table 3.

Table 3. Exploratory Learning and Performance Dimensions.

\begin{tabular}{|c|c|c|c|c|c|c|}
\hline Statement/ Exploratory Learning & Performance Dimensions & $\mathbf{N}$ & Min & Max & Min & Std Dev \\
\hline \multirow{3}{*}{$\begin{array}{l}\text { Extent to which search for knowledge of new } \\
\text { markets influence performance }\end{array}$} & Process Efficiency & 119 & 1 & 5 & 3.472 & 0.932 \\
\hline & Product quality & 119 & 1 & 5 & 3.977 & 0.917 \\
\hline & Customer Satisfaction & 119 & 1 & 5 & 4.050 & 0.869 \\
\hline \multirow{2}{*}{$\begin{array}{l}\text { Extent to which search for knowledge of new } \\
\text { technology influence performance }\end{array}$} & Product quality & 119 & 1 & 5 & 4.334 & 0.724 \\
\hline & Customer Satisfaction & 119 & 1 & 5 & 4.173 & 0.802 \\
\hline \multirow{2}{*}{$\begin{array}{l}\text { Extent to which search for knowledge of new } \\
\text { product development influence performance } \\
\text { dimensions }\end{array}$} & Process Efficiency & 119 & 1 & 5 & 3.751 & 1.009 \\
\hline & Customer Satisfaction & 119 & 1 & 5 & 4.225 & 0.741 \\
\hline
\end{tabular}

Source: Njoroge (2021).

The results in table 3 reveal that exploratory learning is critical to performance dimensions of process efficiency, product quality and customer satisfaction. Search for knowledge of new markets has a high influence on product quality (Mean 3.977) and customer satisfaction (Mean 4.050). However, it has only a moderate influence on process efficiency (Mean 3.472). Search for knowledge of new technology has a high influence on all the three dimensions of performance, process efficiency (Mean 4.266), product quality (4.334) and customer satisfaction (4.173). Similarly, search for knowledge of new product development has very high influence on product quality (4.486), high influence on customer satisfaction (4.225) and relatively high influence on process efficiency (3.751). These findings show that exploratory learning to a high extent influences performance in commercial banks in Kenya. This signifies that if firms invest in exploratory learning then they will gain value in critical areas of performance. The findings are consistent with past studies $[12,18,19]$.

\subsection{Resource Flexibility}

Resource flexibility practices, structuring, bundling and leveraging scarce resources, was examined in order to establish how firms managed their resources for exploratory learning and to enhance performance. On the question of whether firms reconfigure resource portfolios in order to 
leverage exploratory learning, it was established that $85 \%$ of resource portfolios are reconfigured for search and operationalization of new markets, $87 \%$ for new product development and $89 \%$ for implementation of new technology. Results on the extent to which scarce resources are restructured, bundled and leveraged for performance dimensions of process efficiency, product quality and customer satisfaction revealed that restructuring of resources was the main practice with process efficiency having a mean of 4.135 , product quality had a mean of 4.168 , and customer satisfaction with high mean of 4.227. The findings also revealed that organizations gain value through bundling and leveraging resource portfolios in the management of scarce resources in that priority is given to high yielding opportunities, cost effective projects and efforts to respond to market, product and customer changes.

\subsection{Correlation between Knowledge Stock and Exploratory Learning}

A correlation analysis to determine the relationship between knowledge stock and exploratory learning was conducted. The test aimed to ascertain whether the relationship was statistically significant at 95\% level of confidence using a two tailed test. The results are presented in table 4.

Table 4. Correlation between Knowledge Stock and Exploratory Learning.

\begin{tabular}{lllll}
\hline Dimension & & Tacit Knowledge & Routines and Procedures & Competencies and Skills \\
\hline \multirow{3}{*}{ Exploratory Learning } & Pearson Correlation & $.686^{* *}$ & $.713^{* *}$ & $.728^{* *}$ \\
& Sig. (2-tailed) & 0.000 & 0.001 & 0.002 \\
& $\mathrm{~N}$ & 119 & 119 & 119 \\
\hline
\end{tabular}

**Correlation is significant at the 0.01 level (2-tailed).

Source: Njoroge (2021).

The results shown in table 4 reveal that there is a strong positive correlation between knowledge stock and exploratory learning. Correlation between tacit knowledge and exploratory learning is statistically significant, $\mathrm{r}=0.686^{* *}$, $\mathrm{p}(0.000)<0.05$, routines and procedures and exploratory learning is statistically significant, $\mathrm{r}=0.713^{* *}, \mathrm{p}(0.001)<$ 0.05 , and competencies and skills and exploratory learning is also statistically significant, $\mathrm{r}=0.728^{* *}, \mathrm{p}(0.002)<0.05$.

Test of Hypothesis:

$\mathrm{HO}_{1}$ : There is no relationship between knowledge stock and exploratory learning in commercial banks in Kenya

The results in table 4 show that knowledge stock variables have statistically significant positive correlation with exploratory learning, $\mathrm{p}<0.05$. The null hypothesis is rejected as the findings imply that there is a relationship between knowledge stock and exploratory learning in commercial banks in Kenya.

\subsection{Correlation Between Exploratory Learning and Performance}

A Pearson correlation of dimension was used to establish the relationship between exploratory learning and performance. The objective of the test was to ascertain whether the relationship was statistically significant at $95 \%$ level of confidence using a two tailed test. The results are presented in table 5 .

Table 5. Correlation between Exploratory Learning and Performance.

\begin{tabular}{lllll}
\hline Dimension & & Knowledge of New Markets & Knowledge of New Technology & Knowledge of New Products \\
\hline \multirow{3}{*}{ Performance } & Pearson Correlation & $.702^{* *}$ & $.749^{* *}$ & $.693^{* *}$ \\
& Sig. (2-tailed) & 0.001 & 0.000 & 0.003 \\
& N & 119 & 119 & 119 \\
\hline
\end{tabular}

**Correlation is significant at the 0.01 level (2-tailed).

Source: Njoroge (2021).

The results shown in table 5 reveal that there is a strong positive correlation between knowledge stock and exploratory learning. Correlation between tacit knowledge of new markets and performance is statistically significant, $\mathrm{r}=0.702 * *, \mathrm{p}(0.001)<0.05$, knowledge of new technology and performance is statistically significant, $\mathrm{r}=0.749 * *, \mathrm{p}$ $(0.000)<0.05$, and knowledge of new products and performance is also statistically significant, $r=0.693^{* *}, p$ $(0.003)<0.05$.

Test of Hypothesis:

$\mathrm{HO}_{2}$ : There is no relationship between exploratory learning and performance in commercial banks in Kenya

The results in table 5 indicate that exploratory learning variables have statistically significant positive correlation with performance, $\mathrm{p}<0.05$. The null hypothesis is rejected as the findings imply that there is a relationship between exploratory learning and performance in commercial banks in Kenya.

\subsection{Effect of Knowledge Stock on Exploratory Learning}

Using regression analysis, the study sought to determine how changes in the independent variable (knowledge stock) influenced changes in the dependent variable (exploratory learning). The results of regression coefficients for independent variable (knowledge stock) are presented in table 6 . 
Table 6. Regression Coefficients for Independent Variables.

\begin{tabular}{|c|c|c|c|c|c|c|}
\hline \multirow{2}{*}{\multicolumn{2}{|c|}{ Model }} & \multicolumn{2}{|c|}{ Unstandardized coefficients } & \multirow{2}{*}{$\begin{array}{l}\text { Standardized coefficients } \\
\text { Beta }\end{array}$} & \multirow[b]{2}{*}{$\mathbf{t}$} & \multirow{2}{*}{ Sig. } \\
\hline & & B & Std. Error & & & \\
\hline \multirow[t]{4}{*}{1} & (Constant) & 3.106 & 1.279 & & 2.428 & .000 \\
\hline & Tacit knowledge & .775 & .623 & .483 & 1.244 & .000 \\
\hline & Routines \& procedures & 689 & .536 & .369 & 1.285 & .000 \\
\hline & Competencies \& skills & .861 & .625 & .538 & 1.378 & .000 \\
\hline
\end{tabular}

Dependent Variable: Exploratory learning.

Source: Njoroge (2021).

The results of multiple regression analysis presented on table 6 indicate that tacit knowledge significantly predicted exploratory learning: $\beta=0.775, p(0.000)<0.05$; routines and procedures significantly predicted exploratory learning: $\beta=0.689, p(0.000)<0.05$; and competencies and skills significantly predicted exploratory learning: $\beta=0.861, p(0.000)$ $<0.05$ at $95 \%$ confidence level. The regression model, therefore is $\mathrm{Y}=2.172+0.775 \mathrm{X}_{1}+0.689 \mathrm{X}_{2}+0.861 \mathrm{X}_{3}+\varepsilon$. Where $\mathrm{X}_{1}$ represents tacit knowledge, $\mathrm{X}_{2}$ represents routines and procedures and $\mathrm{X}_{3}$ represents competencies and skills.

Test of hypothesis:

$\mathrm{HO}_{3}$ : Knowledge stock has no effect on exploratory learning in commercial banks in Kenya

It is evident from the results in table 6 that knowledge stock variables predict exploratory learning at 95\% confidence level. Therefore, the null hypothesis was rejected. These findings imply that knowledge has significant effect on exploratory learning in commercial banks in Kenya. The findings are consistent with past studies that have established that knowledge stock influences exploratory learning [6].

\subsection{Effect of Exploratory Learning on Performance}

The regression analysis used to examine how changes in the exploratory learning variables (knowledge of new markets, knowledge of new technology and knowledge of new products) influenced changes in the performance. The results of regression coefficients for independent variables (exploratory learning) are presented in table 7.

Table 7. Regression Coefficients for Independent Variables.

\begin{tabular}{lllllll}
\hline \multirow{2}{*}{ Model } & & \multicolumn{2}{c}{ Unstandardized coefficients } & Standardized coefficients & \multirow{2}{*}{ t } & \multirow{2}{*}{ Sig. } \\
\cline { 3 - 6 } & & B & Std. Error & Beta & 2.611 & .000 \\
\\
\cline { 2 - 6 } & (Constant) & 2.172 & .832 & .186 & 1.497 & .000 \\
& knowledge of new markets & .527 & .352 & .299 & 1.476 & .000 \\
& knowledge of new technology & .664 & .450 & .384 & 1.329 & .000 \\
\hline
\end{tabular}

Dependent Variable: Performance.

Source: Njoroge (2021).

The results of multiple regression analysis presented on table 7 indicate that knowledge of new markets significantly predicted performance: $\beta=0.527, p(0.000)<0.05$; knowledge of new technology significantly predicted performance: $\beta=0.664, p$ $(0.000)<0.05$; and knowledge of new products significantly predicted performance: $\beta=0.714, p(0.000)<0.05$ at $95 \%$ confidence level. The regression model, therefore is $\mathrm{Y}=2.172+$ $0.527 \mathrm{X}_{1}+0.664 \mathrm{X}_{2}+0.714 \mathrm{X}_{3}+\varepsilon$. Where $\mathrm{X}_{1}$ represents knowledge of new markets, $\mathrm{X}_{2}$ represents knowledge of new technology and $\mathrm{X}_{3}$ represents knowledge of new products.

Test of hypothesis:

$\mathrm{HO}_{4}$ : Exploratory learning has no effect on performance in commercial banks in Kenya

It is evident from the results in table 7 that exploratory learning variables predict performance at $95 \%$ confidence level. Therefore, the null hypothesis was rejected. These findings imply that exploratory learning has significant effect on performance in commercial banks in Kenya. The findings are consistent with past studies that have established similar results [7].

\subsection{Moderating Effect of Resource Flexibility}

The study determines the moderation effect of resource flexibility on the relationship between exploratory learning and performance using regression analysis. The first step in testing for moderation was to determine whether there was a relationship between exploratory learning and performance to moderate. Table 8 present the results of the regression analysis.

Table 8. Coefficients for Exploratory Learning and Employees' Performance.

\begin{tabular}{|c|c|c|c|c|c|c|}
\hline \multirow{2}{*}{ Model } & & \multicolumn{2}{|c|}{ Unstandardized coefficients } & \multirow{2}{*}{$\begin{array}{l}\text { Standardized coefficients } \\
\text { Beta }\end{array}$} & \multirow{2}{*}{$\mathbf{t}$} & \multirow{2}{*}{ Sig. } \\
\hline & & B & Std. Error & & & \\
\hline 1 & (Constant) & 2.172 & .832 & & 2.611 & .000 \\
\hline & Exploratory learning & .627 & .499 & .501 & 1.257 & .000 \\
\hline
\end{tabular}

Dependent Variable: Performance.

Source: Njoroge (2021). 
The results indicated that there was an effect to moderate, intercept, $\beta_{0}=2.172, p(0.000)<0.05$; organizational learning, $\beta=0.627, p(0.000)<0.05$ as shown in table 8

Table 9. Coefficients of Moderation Analysis.

\begin{tabular}{|c|c|c|c|c|c|c|}
\hline \multirow{2}{*}{\multicolumn{2}{|c|}{ Model }} & \multicolumn{2}{|c|}{ Unstandardized coefficients } & \multirow{2}{*}{$\begin{array}{l}\text { Standardized coefficients } \\
\text { Beta }\end{array}$} & \multirow{2}{*}{ t } & \multirow{2}{*}{ Sig. } \\
\hline & & B & Std. Error & & & \\
\hline \multirow[t]{4}{*}{1} & (Constant) & 3.647 & 1.052 & & 3.467 & .000 \\
\hline & Exploratory learning & .579 & .540 & .313 & 1.072 & .000 \\
\hline & Resource flexibility & 1.738 & 0.633 & .629 & 2.755 & .000 \\
\hline & (Constant) & 4.183 & 1.251 & & 3.344 & .000 \\
\hline \multirow{3}{*}{2} & Exploratory learning & .397 & .109 & .104 & 3.642 & .168 \\
\hline & Resource flexibility & 2.715 & 1.035 & .526 & 2.623 & .003 \\
\hline & $\mathrm{EL} * \mathrm{RF}$ & .078 & .021 & .493 & 3.714 & .001 \\
\hline
\end{tabular}

Dependent Variable: Performance.

Source: Njoroge (2021).

The results in table 9 indicate exploratory learning, $\beta=0.397, p(0.168)>0.05$ which implies that exploratory learning is a predictor of performance. On the other hand, resource flexibility, $\beta=2.715, p(0.003)<0.05$, which implies that resource flexibility is not a predictor variable but a moderator variable. The coefficient for the interaction term, $\beta=0.078, p(0.001)<0.05$ indicates that resource flexibility has moderator effect on the relationship between exploratory learning and performance with a total effect of 7.8 percent.

Test of hypothesis:

$\mathrm{HO}_{5}$ : Resource flexibility has no moderating effect on the relationship between exploratory learning and performance in commercial banks in Kenya

The proposed null hypothesis that resource flexibility has no moderation effect on the relationship between exploratory learning and performance was rejected since the coefficient for the interaction term, $\beta=0.078, p(0.001)<0.05$ indicates that resource flexibility has moderator effect on the relationship between exploratory learning and performance with a total effect of 0.067 at $95 \%$ confidence level. These findings are consistent with past studies that have found moderation effect of resource flexibility [44].

\section{Conclusions}

The study has established a linkage between knowledge stock, exploratory learning and performance. Knowledge stock which was indicated by tacit knowledge, routines and procedures and competencies and skills has significant influence on exploratory learning dimensions of searching knowledge for new markets, new technology and new product development. Knowledge stock is an antecedent of exploratory learning which ensure from different knowledge processing paths such as tacit knowledge, routines and procedures and competencies and skills. As a precursor of exploratory learning, knowledge stock guides the way new information and knowledge is manipulated for positive organizational outcomes by providing the elements and capabilities that cements the impact of learning on firm performance. These findings relate to empirical evidence that has pointed to the positive influence of knowledge stock on learning and on organizational outcomes.
Exploratory learning has a statistically significant positive correlation with performance. The results also indicated that exploratory learning predicts performance. Searching and acquisition of knowledge for new markets, new technology and new product development have high influence on process efficiency, product quality and customer satisfaction. Exploratory learning activities provides the organization with the capacity to adapt to changing business environment in terms of markets, technology and products as it is well equipped with necessary knowledge and information on the new frontiers. In addition, it provides the organization with flexibility critical for growth in areas of market expansion, product quality improvement and customer satisfaction. These dimensions of performance which are key indicators of a firm's current viability and survival are impacted by the extent of exploratory learning activities adopted by the organization. Therefore, it is important that firms invest in exploratory learning activities to drive firm performance.

The results have established that resource flexibility has a moderating effect on the relationship between exploratory learning and performance. It was determined that resource portfolios are reconfigured for search and operationalization of new markets, new product development and implementation of new technology. Further, scarce resources are restructured, bundled and leveraged for performance dimensions of process efficiency, product quality and customer satisfaction. It is evident that organizations gain value through bundling and leveraging resource portfolios in the management of scarce resources in that priority is given to high yielding opportunities, cost effective projects and efforts to respond to market, product and customer changes.

\section{References}

[1] Njoroge, P. T. \& Muathe, S. M. (2018). Linking Ambidextrous Learning with Organizational Performance: Critical Review of Literature and a Research Agenda. European Journal of Business and Management, 10 (6): 32-47.

[2] Ahuja, G., Lampert, C. M. (2001). Entrepreneurship in the large corporation: a longitudinal study of how established firms create breakthrough inventions. Strategic Management Journal, 22 (6-7): 521-543. 
[3] Katila, R. \& Ahuja, G. (2002). Something old, something new: A longitudinal study of search behavior and new product introduction, Academy of Management Journal, 45 (5): 11831194.

[4] March, J. G., (1991). Exploration and exploitation in organizational learning. Organization Science 2 (1): 71-87.

[5] Atuahene-Gima, K. \& Murray, J. Y. (2007). Exploratory and exploitative learning in new product development: a social capital perspective on new technology ventures in China. Journal of International Marketing, 15 (2): 1-29.

[6] Lee, C. \& Huang, Y. (2012). Knowledge stock, ambidextrous learning, and firm performance: Evidence from technologically intensive industries. Management Decision, 50 (6): 1096-1116.

[7] Li, Y., Wei, Z., Zhao, J., Zhang, C. \& Liu, Y. (2013). Ambidextrous organizational learning, environmental munificence and new product performance: Moderating effect of managerial ties in China. International Journal of Production Economics. 146: 95-105.

[8] Birkinshaw, J., \& Gupta, K. (2013). Clarifying the distinctive contribution of ambidexterity to the field of organization studies. Academy of Management Perspectives, 27: 287-298.

[9] Patel, P. C., Messersmith, J. G., \& Lepak, D. P. (2013). Walking the tightrope: An assessment of the relationship between high-performance work systems and organizational ambidexterity. Academy of Management Journal, 56: 1420 1442.

[10] Njoroge, P. T., Bula, H. \& Wanyoike, R. (2020). Examining the Effect of Knowledge Acquisition and Information Distribution Employees' Performance in Classified Hospitality Firms in Kenya. Journal of Human Resource Managem ent, 8 (3): 200-208. DOI: 10.11648/j.jhrm.201200803.21.

[11] Njoroge, P. T., Bula, H. \& Wanyoike, R. (2020). Moderating Effect of Organizational Culture on the Relationship between Organizational Learning and Employees' Performance in Classified Hospitality Firms in Kenya. International Journal of Business and Management, 15 (12): 51-61. DOI: 10.5539/ijbm.v15n12p51.

[12] Caniëls, M. \& Veld, M. (2016). Employee ambidexterity, high performance work systems and innovative work behaviour: How much balance do we need? The International Journal of Human Resource Management, DOI: 10.1080/09585192.2016.1216881.

[13] Argote, L. (2011). Organizational learning research: Past, present and future. Management Learning, 42 (4), 439-446.

[14] Chiva, R., Alegre, J., \& Lapiedra, R. (2007). Measuring organisational learning capability among the workforce. International Journal of Manpower, 28 (3/4), 224-242.

[15] Easterby-Smith, M. \& Lyles, M. A. (2003). Introduction watersheds of organizational learning and knowledge management. In the Blackwell handbook of organizational learning and knowledge management. Edited by M. EasterbySmith and J. Burgoyne. Malden/USA: Blackwell.

[16] 16. Cohen W. \& Levinthal, D. (1990). Absorptive capacity: a new perspective on learning and innovation. Administration Science, 35 (1): 128-152.
[17] Auh, S. \& Menguc, B. (2005). Balancing exploration and exploitation: the moderating role of competitive intensity. Journal of Business Research, 58 (12): 1652-1661.

[18] Ajayi, O. M., Odusanya, K. \& Morton, S. (2017). Stimulating employee ambidexterity and employee engagement in SMEs. Management Decision, 55 (4): 662-680.

[19] Gomes, G. \& Wojahn, R. M. (2016). Management Organizational learning capability, innovation and performance: study in small and medium-sized enterprises (SMES).

[20] Raisch, S., \& Birkinshaw, J. (2008). Organizational ambidexterity: Antecedents, outcomes, and moderators. Journal of Management, 34: 375-409.

[21] Cao, Q. Gedajlovic, E. \& Zhang, H. (2009). Unpacking organizational ambidexterity: dimensions, contingencies, and synergistic effects. Organization Science, 20 (4): 781-796.

[22] Gibson, C. B., \& Birkinshaw, J. (2004). The antecedents, consequences, and mediating role of organizational ambidexterity. Academy of Management Journal, 47: 209-226.

[23] He, Z. L. \& Wong, P. K. (2004). Exploration vs. exploitation: an empirical test of the ambidexterity hypothesis. Organization Science, 15 (4): 481-494.

[24] Lin, Z., Yang, H. \& Demirkan, I. (2007). The performance consequences of ambidexterity in strategic alliance formations empirical investigation and computational theorizing. Management Science, 53; 1645-1658.

[25] Mom, T. J., Fourné, S. P., \& Jansen, J. J. (2015). Managers' work experience, ambidexterity, and performance: The contingency role of the work context. Human Resource Management, 54: 133-153.

[26] Raisch, S., Birkinshaw, J., Probst, G. \& Tushman, M. L., (2009). Organizational ambidexterity: balancing exploitation and exploration for sustained performance. Organization Science, 20 (4): 685-695.

[27] Drucker, P. F. (1986). Innovation and Entrepreneurship: Practice and Principles. New York: Harper Business.

[28] Grant, R. M. (1996). Toward a Knowledge-based Theory of the Firm. Strategic Management Journal, 17 (winter): 109-122.

[29] Rhee, J., Park, T. \& Lee, D. H. (2010). Drivers of innovativeness and performance for innovative SMEs in South Korea: mediation of learning orientation. Technovation, 30 (1): $65-75$.

[30] Sutanto, E. M. (2017). The influence of organizational learning capability and organizational creativity on organizational innovation of Universities in East Java, Indonesia Asia. Pacific Management Review, 22: 128-135. doi.org/10.1016/j.apmrv.2016.11.002.

[31] Wadhwa, A. \& Kotha, S. (2006). Knowledge creation through external venturing: evidence from the telecommunications equipment manufacturing industry. Academy of Management Journal, 49 (4): 1-17.

[32] Lin, H \& Lee, Y. (2017). A Study of the Influence of Organizational Learning on Employees' Innovative Behavior and Work Engagement by a Cross-Level Examination. Journal of Mathematics Science and Technology Education, 13 (7); 3463-3478. 
[33] Fletcher, M. \& Prashantham, S. (2011). Knowledge assimilation processes of rapidly internationalizing firms: Longitudinal case studies of Scottish SMEs. Journal of Small Business and Enterprise Development, 18 (3): 475-501.

[34] Gelard, P., \& Mirsalehi, S. P. (2010). The Relation between Organizational Learning Capability and Product Innovation Performance: An Empirical Test in Iranian Organizations. Paper presented at European Conference on Innovation and Entrepreneurship.

[35] Huber, G. P. (1991). Organizational Learning: The Contributing Processes and the Literatures. Organization Science, 20 (1), 88-115.

[36] Richards, G. S. \& Duxbery, L. (2014) Work-Group Knowledge Acquisition in Knowledge Intensive Public-Sector Organizations: An Exploratory Study, Journal of Public Administration Research and Theory, 25 (4).

[37] Sola, O. A. \& Ayobami, A. P. (2013). Strategic Impact of Knowledge Management and Organizational Learning on the Perceived Performance of Selected Banks in Oyo State of Nigeria. Journal of Economics and Sustainable Development, 4 (2): 45-54.

[38] Scott, B. B. (2011). Organizational Learning: A Literature Review. IRC Research program, Queen's University IRC.

[39] Senge, P (1990). The Fifth Discipline: The art and practice of the learning organization, London, Doubleday.

[40] Lee, C. Y., Wang, M. C. \& Lin, J. C. (2011). The effects of a focal firm's internal and external boundary conditions on the performance implication of R\&D alliance participation. IEEE International Technology Management Conference, 575-586.

[41] Alvarez, S. A., \& Barney, J. B. (2007). Discovery and creation Alternative theories of entrepreneurial action. Strategic Entrepreneurship Journal, 1 (1): 11-26.

[42] Sirmon, D. G., Cove, S., Hitt, M. A. Ireland, R. D. \& Gilbert, B. A. (2011). Resource orchestration to create competitive advantage: Breadth, depth and life cycle effects. Journal of Management, 37 (5): 1390-412.

[43] Sirmon, D. G., Cove, S. \& Hitt, M. A. \& Ireland, R. D. (2007). Managing firm resources in dynamic environments to create value: Looking inside the black box. Academy of Management Review, 32 (1): 273-93.
[44] Sirmon, D. G., Cove, S. \& Hitt, M. A. (2008). Resource management in dyadic competitive rivalry: The effects of resource bundling and deployment. Academy of Management Journal, 51 (5): 919-35.

[45] Zhou, C. Z., \& Wu, F. (2010). Technological capability, strategic flexibility, and product innovation. Strategic Management Journal, 31 (5): 547-61.

[46] Kaplan, R. S., \& Norton, D. P. (1992). The Balanced Scorecard - Measures that drive performance. Harvard Business Review, Jan-Feb: 71-79.

[47] Kaplan, R. S., \& Norton, D. P. (1996). The Balanced Scorecard: Translating strategy into action. Boston, Ma: Harvard Business School Press.

[48] Sink, D. S. \& Tuttle, T. (1989). Planning and Measurement in your Organization of the Future. Norcross GA: Industrial Engineering and Management Press.

[49] Delaney, J. T., \& Huselid, M. A. (1996). The Impact of Human Resource Management Practices on Performance in for-Profit and Nonprofit Organizations. Academy of Management Journal, 39: 949-969.

[50] Creswell, J. W. (2009). Research Design: Qualitative and Mixed Methods Approaches. SAGE: London, UK.

[51] Bajpai, N. (2011). Business Research Methods. India, Pearson Education.

[52] Saunders, M., Lewis, P. \& Thornhill, A. (2009). Research Methods for Business Students. $5^{\text {th }}$ Edition, Pearson Education Limited, Edinburgh, England.

[53] Central Bank of Kenya (2020). Directory of Licensed Commercial Banks, Mortgage Finance Institutions and Authorized Non-Operating Holding Companies in Kenya. $\mathrm{http} / /$ :www.centralbank.go.ke.

[54] Cooper, D. R. \& Schindler, P. S. (2013). Business Research Methods. $12^{\text {th }}$ Edition, McGraw-Hill Higher Education.

[55] Hair. J. F. Jr., RE. Anderson, R. L., Tatham \& W. C. Black. (2012). Multivariate Data Analysis with Readings. New Jersey, Englewood Clifts, NJ: Prentice Hall. 